years he was Treasurer of the Linnean, and also of the Geological, Society.

Dr. Gwyn Jeffreys's profession was the law. He practised as a solicitor at Swansea until 1856 , in which year he was called to the bar, but soon afterwards altogether retired from business. He then left London, and went to reside at a fine old house, Ware Priory, which he had purchased in Hertfordshire. Here it was his delight to hospitably entertain his scientific friends and any foreign naturalists of kindred tastes to his own who might be visiting London.

He may be considered perhaps as the father of dredging in our seas. When practising as a solicitor he was diligent in his profession, and could only spare himself short holidays ; yet as early as I84I he paid his first visit to Shetland. Through a number of years, when unable to give much time himself to collecting, he joined Mr. Barlee in partnership, and while his friend gave his whole time to dredging and collecting, Jeffreys shared the expense and the mollusca.

Shortly after Barlee's death Jeffreys was enabled to devote himself more exclusively to scientific work, and from this time commenced an important series of dredging operations which continued to the last. His friends were now the late Mr. Waller and the Rev. A. M. Norman, and in company with these naturalists explorations were made of the most important parts of the British coasts. A yacht, the Osprey, at first lent by Dr. Gwyn Jeffreys's brother-in-law, Mr. Nevill, but subsequently purchased by him, was employed in these investigations. The summers of $186 \mathrm{I}, 1862,1863,1864,1867$, and 1868 were spent in dredging, down to 170 fathoms, the sea around the Shetland Islands; in 1865 Guernsey and Jersey were visited in 1866 the Minch; and in 1870 the deep water off Valentia on the south-west of Ireland.

Private enterprise now gave way to Government expeditions. In 1869 H.M.S. Porcupine was sent to explore that portion of the Atlantic which lies off our western shores, and Dr. Gwyn Jeffreys had charge of the scientific work of the first cruise off the west of Ireland. In the succeeding year (1870) the same vessel was sent to investigate the great depths off the southern coasts of Europe, and Jeffreys was the naturalist on board during the first cruise, which was off the Spanish and Portuguese coasts. In 1876 he went in H.M.S. Valorous, which accompanied the last Arctic Expedition as far as Baffin's Bay, when very successful dredging was carried on in Davis Strait and the North Atlantic Ocean during the homeward voyage. In 1880 he and his friend, Dr. Norman, by invitation of the French Government, took part, with a staff of naturalists of that country, in dredgings in great depths off the Bay of Biscay in Le Trawailleur. In 1878 and 1879 Drs. Gwyn Jeffieys and Norman went together to Norway and dredged Oster Fiord to the north of Bergen, the Hardanger Fiord, and at Lröbak on the Christiania Fiord.

Besides all this dircet scicntific collecting Dr. Jeffreys for many years has been in the habit of taking a tour on the Continent for the purpose of carefully examining all leading and typical collections of European mollusca, and more especially the products of the various deep-sea expeditions of other nations.

He married a daughter of the late R. J. Ncrill, Esq. of Llangennech Park, Carmarthenshirc, a talented and accomplished woman who prodeceased him, and has left six children.

Dr. Gwyn Jeffreys was J.P. for the counties of Glamorganshire, Breconshire, and Hertfordshire, and for the last county was also a D.L., and served as High Sheriff in 1877 .

It cannot but be a matter of deep regret to all British naturalists that Dr. Gwyn Jeffreys's magnificent and un equalled collection of European mollusca, amassed with so much labour and toil and expense, rich to overflowing with types not only of species described by himself, but by almost every author, should go out of this country. Two years ago it was purchased by the American Government. We congratulate our Transatlantic cousins on having it, but it would have been of far greater value in Europe.

\section{ALEXANDER MURRAY, C.M.G.}

$\mathrm{BY}$ the death of Mr. Alexander Murray, Canadian geology has lost one of its veteran pioneers. This estimable man belonged to a good Perthshire family, and was born at his father's estate of Dollerie in I8II. He went into the navy at the age of fourteen, served in the Meditcrranean and was present at the battle of Navarino, was subsequently employed in the West Indies, Halifax, and other stations, and finally quitted the service in 1837 . There being no prospect of his advancement in the pursuit of war, he turned his attention to the arts of peace, went to Canada, and bought land there with the view of settling as a farmer. During the rebellion which broke out soon after his emigration he had once more an opportunity of seeing active service. But he had not yet found the proper field for the exercise of his powers. His attempts at farming failed, and his prospects were rather blank, when at last he made the acquaintance of Mr. W. E. Logan, then starting the Geological Survey of Canada. He had had no training in science of any kind, but the mode of life offered by the Survey seemed just what he longed for, and he gladly accepted the proposal that he should join the staff. Before actually beginning his new cluties he resolved to do what he could to qualify himself for them. He returned to this country, studied geology theoretically at Edinburgh, and afterwards practically in Wales. In I 843 he went back to Canada and at once began work, remaining at his post for twenty years. He was one of the first and ablest of the stratigraphers with whom Logan traced out the general geological structure of the Dominion. His explorations extended over most of the settled parts and over a large arca of forest-land in Western Canada, where he laid down the main lines of structure and the areas of distribution of the rocks. He likewise examined parts of Gaspé and other tracts in the eastern portion of the Dominion. But his most important labours were devoted to the investigation of Newfoundland, of the Geological Survey of which he had charge from I 863 to I 883 . From I 866 onwards he prepared an Annual Report of the progress of his work in that colony. These Reports collected by him, and republished as a volume in $\mathrm{I} 88 \mathrm{I}$, contain a summary of all that is known regarding the geological structure of Newfoundland, and will remain as a lasting monument of Mr. Murray's skill as a stratigraphical geologist, and of the courage, patience, aad tact with which he overcame all physical and political difficulties. One of his last labours was the completion and publication of a geological map of the whole of Newfoundland - a work at once beautiful in execution and of the first importance in regard to the inclustrial growth of the colony. Very few of our colonies yet posscss complete geological maps, and hardly ever are they so largcly the work of one man as this one. New foundland has never ade fuately recognised how much it stands indebted to Mr. Murray for his share in laying the foundation on which its future devclopment must rest.

\section{SEARLES $V$. WOOD}

A MONG the recent losses which have befallen the geologists of this country not the least is the death of Mr. Searles V. Wood. Himself the son of a geologist, he began his scientific work early in life. He may be said to have been educated upon Tertiary geology, and though at first disposed to wander intr wider fields of 